\section{VIEWS AND EXPERIENCES DF PRE-SERVICE TEACHERS DN THE USE DF STORIES IN TEACHING SCIENCE}

\author{
Burcu Anilan
}

\section{Introduction}

With the advances in science and technology, competencies and qualities required in individuals as the building stones of a society also change. The change in qualities required in individuals in the modern world has naturally an impact on the approach to education and the use of different methods and techniques in teaching-learning processes becomes important.

The thought system related to knowledge and knowing has begun to change with the contemporary teaching methods, and the ability to access knowledge or to use knowledge has gained more importance rather than knowing knowledge (Çalışkan, 2008). Since the fact the teacher describes a course only by using the direct instruction method in the traditional learning environments allows a learning environment, where the teacher is active and the student is passive, the students do not find an environment to apply any information learnt by the student and a possibility to structure such information and the effective learning environment is not provided (Unal \& Akpinar, 2006). In the field of education, the traditional learning methods have been replaced by the new methods, techniques, strategies and approaches, and the methods and techniques, in which students have active roles and which ensures interpreting and configuring knowledge with mental activities instead of directly taking them, have become usable.

An effective science education can be achieved by ensuring meaningful learning and internalization of concepts rather than encouraging students to memorization. Because knowledge learned by memorizing shall not be remembered for a long time, and it shall adversely affect learning of new concepts (Maskan \& Maskan, 2007). Ayas (1995) argues that science has great importance in development of the countries, and for this reason, different approaches are experienced in development and application of science teaching programs. The main purpose of the curriculum of science courses is to train all students in science literacy regardless of their individual differences. According to the educational program of science courses, audiovisual aids used in education with a learning objective which is one of these aids is one of the most effective ways to ensure permanent learning (Köklükaya, 2015). On the other hand, Appleton (2003) emphasizes that the practical activities are the most convenient time frame for understanding a subject. In this context, it can be stated that it is quite important to benefit from different

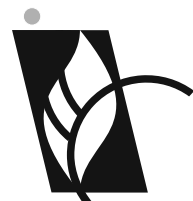

J O U R N A L

$\mathrm{O} F \bullet \mathrm{B} \mathrm{A} \mathrm{L} \mathrm{T} \mathrm{I} \mathrm{C}$

$S$ C I E N C E

E DUCATION

ISSN 1648-3898 /Print/ ISSN 2538-7138 /Online/

Abstract. The research aims to determine the experiences and views of the science pre-service teachers on the use of the science stories. In this research, among other qualitative research types, phenomenology research was used to obtain data. The research has been carried out with 71 pre-service teachers studying in the science education program of education faculty. The data has been analyzed based on the content analysis technique. The views of the pre-service teachers on the use of stories in science courses have been categorized under 6 themes. It has been concluded that teaching science with stories shall contribute to knowledge and competencies of both teachers and students, the science courses shall become more entertaining, joyful and interesting. In addition, it has been emphasized that creativity of students shall develop in the story composition process, their imagination shall increase, they shall configure their knowledge associating it with the daily life, meaningful learning shall be ensured by concretizing mostly abstract science subjects and concepts through stories, and a learning environment to ensure memorability of knowledge shall be prepared.

Keywords: phenomenology, science teaching, science stories, science preservice teachers.

Burcu Anilan Eskişehir Osmangazi University, Turkey 
methods, techniques and approaches for a more quality education-teaching process in science courses (Ayvacı \& Şenel Çoruhlu, 2009).

Another method consisting of the practical activities that can be effectively used in order to enable students to configure knowledge and interpreting it by using in daily life is the narration method (Akçay, Özyurt \& Akçay, 2014). The narratives that can be used in other fields as well as in science and have an important place in the inner world of the individual since childhood affect learning positively (Milne, 1998). The stories have become one of the most frequently used educational methods in daily life from past to present. Many researchers have supported the use of stories and storytelling both as a strong and also as an entertaining tool to explain science in a convincing way to people (Avraamidou \& Osborne 2009; Negrete \& Lartigue 2010; Dahlstrom, 2014; Kaplan \& Dahlstrom 2017; Martinez-Conde \& Macknik 2017; as cited in Kirby 2018).

Strauss (2006) defines a story as a narrative of a real, fictional, or mythical event. The tales develop a fictional world for students as directed by new heroes (Ødegaard, 2003). Story has been described by Oğuzkan (1987) as "short texts narrating a realistic event experienced by several persons at a certain time and place or drawing the character of some people and often making up of just a few pages". Stories can be handled as narrative, fiction and literary text. Fictional texts vary from other text types with their characteristics such as form, content, fiction, narration, metaphor, etc. (Dilidüzgün, 2003). According to Sever (2003), the text should address students in terms of age, interest and need, and students' imaginary and emotion world should be in harmony with the content pattern of texts. In addition to these, "the messages that could affect students negatively should not contain violence, pessimism, etc."The studies on multiple writing activities carried out in science courses contain the multiple writing types such as writing stories, letters, poems, reports, explanations, diary on the subject, preparing brochures, posters, diagrams and concept maps. Studies have been performed on these types of writing activities at home (Akyol \& Dikici, 2009; Çardak, 2010; Duru \& Gürdal, 2002; Günel, Atila, \& Büyükkasap, 2009 and abroad Akkuş, Günel, \& Hand, 2007; Hand, Hohenshell \& Prain, 2004; Hohenshell \& Hand, 2006; Mason \& Boscola, 2000 (as cited in Akçay, Özyurt, \& Akçay, 2014).

While writing the tales to be used in courses, teachers should prepare their main ideas, the list of concepts or facts, storify them in a creative style by choosing specific places, events and heroes (Saban, 2001). Stories issued in a way, in which students shall enjoy learning as much as possible and develop positive attitudes, make up good methods to use while narrating about the concepts and inter-conceptual relations (Demircioğlu, Demircioğlu, \& Ayas, 2006). The listener is often in a passive position in use of story in education. Although the listener is in a passive position, he/she can perform learning at the level of understanding and comprehension. However, the individual writing the story learns his/her story and the lesson (knowledge) embedded in the story more permanently. In this way, higher level cognitive learning such as synthesis and assessment can be performed (Turgut \& Kışla, 2015). Tales also help us connect with our previous knowledge, and accordingly, it strengthens our memory (Schank 1990). Consequently, well-prepared tales are remembered by learners (Lowenthal \& Dunlap, 2010). In this context, the tale narration method can help facilitate learning, and make such learning permanent. Teachers may require their students to create stories in line with certain limitations according to the learning needs of their students and the nature of the subject to be narrated. The fact that the students are involved in tale creation, narration and within the tale itself allows them to be involved in a learning-teaching process, in which they form and configure their learning themselves. As they think about the subject and evaluate it on their own, effective learning is achieved. In addition, the ability of students to think, evaluate and criticize also develops (Uluğ, 2004). Thanks to the tales, courses become more interesting and enjoyable. Tıngöy, Güneşer, Öngün, Demirağ and Köroğlu (2006) argue that narration allows the students to interact as listeners or narrators, and in both cases, narration encourages the students to increase their listening, reading and comprehension abilities (as cited in Duman \& Göçen, 2015). The story activities enable children to solve problems, demonstrate their imagination, develop their creativity, and reflect their inner world experiences (Zembat \& Zülfikar, 2006). Stories enable teachers to bring humanistic aspects into the science classroom. Moreover, stories can also be used to create controversies in the classroom as a good story contains also a conflict situation in which the protagonist has to make a crucial decision (Heering, 2014). Researches indicate that stories do not just support the child's language development, but also affect social development positively (Isbell, Sobol, Lindauer, \& Lowrance, 2004; Morris, Taylor \& Wilson, 2000).

Osborne (1997) claims that there are many strategies that can be used by science teachers in classrooms. One of these strategies is story-telling. Stories are one of the strongest tools that can potentially be used when teaching science. There are many benefits for science teachers in using stories as an alternative tool in the learning-teaching process (Kumari, 2014). 
When the literature studies on use of stories in science courses are examined, in their studies, Orçan and İngeç (2016) have stated that science fiction stories developed with comic book technique in physics teaching are effective in development of students' creative thinking skills. In their studies on purposes of story-based teaching program, explanatory stories and use of the chemical stories in the learning environment, Demircioğlu, Demircioğlu, and Ayas (2006) have concluded that the chemical stories increase students' willingness to learn and carry out meaningful learning. In Tao's (2002) research conducted with the 7-year-old students, it has been seen that the scientific stories are handled as an explanatory story-telling method, and its effect especially on the opinions on the nature of science has been researched. At the end of his research, the researcher stated to have observed that the students were highly influenced by the scientific tales, and that their views on its nature have changed. Ayvacı and Şenel-Çoruhlu (2009) have examined the effect of the explanatory story-telling method in correcting the misconceptions on physical and chemical change subjects. Erten, Kıray, and Şen-Gümüş (2013) have aimed to determine the scientist image through scientific narration method. Çıralı and Usluel (2015) have researched the effect of digital story-telling method on students' visual memory and writing skills. Bostan Sarıoğlan (2014) has examined the relationship between pre-service teachers' high cognitive abilities and their scientific stories writing abilities. Mutonyi (2016) has researched the effects of stories, proverbs, and anecdotes on configuring scientific concepts. The results obtained from of Gölcük's (2017) research based on the qualitative data also indicate that students have developed a positive view on the science course supported by scientific stories. When all these studies are examined and the spread of use of stories in science courses and their contributions to learning are taken into consideration, it is clear that the views and experiences of teachers and pre-service teachers on use of stories in science teaching, one of the most important elements of education, are important in carrying out an effective educational activity.

On the other hand, the organic chemistry courses, which create a practice base for the views and experiences of pre-service teachers on use of stories in science teaching, have an important place in science teaching programs. Because, in daily life, we encounter many organic compounds in the neighborhood. First of all, the proteins, carbohydrates, enzymes, RNA, DNA that constitute our bodies are organic, and all the reactions occurring in our bodies are formed with organic compounds. For this reason, a good understanding of organic chemistry is also quite important for creation of a view on the life. Because if students can interpret the information they learn in the organic chemistry courses in their daily lives, science literacy gain, one of the aims of science education, shall be achieved a little more. For this reason, the courses can be supported with model use, computer animations display, group and project studies and inquiry-based experiments, so that students can learn concepts related to the organic chemistry course more easily and meaningfully (Ghaffari, 2006). This research aims to determine the experiences and views of the science pre-service teachers on the use of the stories created as part of organic chemistry courses in science courses.

\section{Methodology of Research}

\section{General Background}

This research focuses on the original stories that pre-service teachers create about organic chemistry and on how these stories can be used in their teaching profession. Within this framework the experiences that preservice teachers have during the process of creating stories are considered to be important. A research has been conducted in qualitative design employing phenomenology approach. Phenomenology focuses on the human experiences that this reality brings about in order to understand the social reality. A phenomenological study is based on concentrating on how people describe something they experience and how they experience (Merriam, 2013, Patton, 2014). Phenomenology provides a wide range of ideas about how we can interpret and examine experiences (Smith, Flowers \& Larkin, 2009). According to Moustakas (1994) in phenomenology what is experienced about a phenomenon and what kinds of context or situation affect the experience about this phenomenon are studied (as cited in Cresswell, 2007).

In this context, experiences related to phenomena are inquired (Ersoy, 2016), and here, the way how people experience the relevant phenomena is described in a methodological, elaborate and in-depth manner, and the perceptions and meanings they develop through their experiences are attempted to be understood (Patton, 2014). This research has also accepted the phenomena attempted to be examined in-depth as science teaching together with the stories and tried to determine the experiences and views of the science pre-service teachers on the use of the stories created as part of organic chemistry courses in science courses. 


\section{Research Group}

The research has been carried out with 71 pre-service teachers, who study in the science education program of a faculty of education in a city located in the Central Anatolian region of Turkey and learn General Chemistry IV (Organic Chemistry) course. Research groups are in the faculty of education founded twenty-one years ago which currently has 2500 students and 92 professors in a university with a history of 50 years which currently has approximately 35000 students. On the other hand, the department of science education programme has been available since the faculty of education was founded. Therefore, it is possible to claim that the research groups are in a well-established and experienced institution. Teaching science inherently includes multidisciplinary and a wide variety of courses. One of these courses is General Chemistry IV (Organic chemistry). This research was conducted with the focus on this course. As there were 71 students enrolled in this course at the time of this research, 71 pre-service teachers participated in this research.

The participants of the research have been determined according to the convenient sampling method, one of the purposeful sampling methods. All pre-service teachers were willing to and volunteered to participate in the research. 18 of the volunteers were male, 53 were female and the age range was 19-20. These teacher candidates, who participated voluntarily in the research, are required to give a statement that they participated voluntarily and intentionally in the research, and a written commitment is given to the teacher candidates that any information and documents obtained from them shall not be shared with the third parties, shall be used only in this research. The parties have mutually signed these documents. Furthermore, the researcher has taken all kinds of precautions to ensure that all information and documents that may reveal the participants' personal information are secured and that they are not disclosed to the wrong person.

\section{Collecting of Data}

Firstly, at the beginning of the research, a sample course has been lectured with a story for the pre-service teachers in the organic chemistry course. Afterwards, a presentation containing sample stories and related to the story creation process has been performed for the pre-service teachers, and the pre-service teachers have been given a 3-week period to create sample stories to be used in teaching organic chemistry subjects. These stories prepared by the pre-service teachers have been collected from them after the required examination, arrangement and classification, and they have been used as "documents and papers" for the data of this research. In addition to this, the experiences of the pre-service teachers in creating the sample stories and their views on this have been obtained through a survey consisting of open-ended questions. This form prepared by the researcher has been applied after it has been shaped by the views and suggestions of the field experts.

\section{Analysis of Data}

The raw data obtained from the surveys and documents have been analyzed and interpreted using the "content analysis technique" (Yıldırım \& Şimşek, 2005). In the research, firstly, the answers given to each question have been brought down. Following breakdown of the data, the themes have been accessed through the answers given to the questions by the pre-service teachers. In this context, the views of the pre-service teachers on the use of stories in science courses have been categorized under 6 themes including "entertaining and enjoyable", "increasing imagination and creative thinking", "better understanding and catchy", "interesting", "abstract-toconcrete", "associating with the daily life". The themes obtained have been broached to two field experts, who are competent in qualitative research, and a consistency study has been conducted. Afterwards, agreements and disagreements have been fixed, and reliability of the research has been determined using the reliability formula of Miles and Huberman: $\mathrm{P}$ (Consensus percentage) $=\mathrm{Na}$ (Agreement)/Na (Agreement) $+\mathrm{Nd}$ (Disagreement) $\mathrm{x} 100$. It has been determined that the harmony between the experts' and the researcher's evaluations is $93 \%$. As this value is over 90 , accordingly, it has been accepted that a high degree of reliability has been achieved. In addition, students' views have been directly and frequently cited in order to increase the internal reliability and validity of the research findings. 


\section{Results of Research}

In this research, which has been carried out to determine the stories by the science pre-service teachers in the organic chemistry course and their views on the use of the story in the science courses, a result of the stories created, the findings obtained from the data have been explained with examples of stories, figures and direct citations from the students' statements.

The story created by one of the pre-service teachers in the organic chemistry course is presented below as an example.

\section{Organic Compounds at School}

On one Monday, Sude does not want to go to the school. However, she has to. Because her teacher has told that he/she is going to teach a very important subject. When Sude goes to the school, she sees that many organic compounds, which she does not know, are written on board in the classroom. All of them have names below. She wonders how these names are assigned. Later on, the teacher comes to the classroom. He/she says that the subject to teach today is naming alkenes, which are among organic chemical compounds. He/she explains that the alkenes are made up of carbon and hydrogen atoms, and it is identified with the general formula " $\mathrm{C}_{n} \mathrm{H}_{2 n+2}$ ", where $n$ represents the number of carbon atoms. And then he/ she makes students write a lot of rules about naming the alkenes. Sude does not understand how these rules will be applied. At that very moment, the school bell rings to end the course, and she goes home as it is the last course.

When she comes home, her mother realizes that Sude is said. She tells her mother that she did not understand today's subject, cannot use and remember its rules. Her mother suggests her daughter another way so that she can understand it. Let's think of naming the organic compounds as a game. There are rules for naming just as the games have. Sude tries to dramatize the naming rules. Sude considers every carbon as a child, every hydrogen as a baby doll and names the alkyl groups like methyl 1 child, ethyl 2 child. Firstly, she chooses the most crowded one among the lined-up children. Because she knows that when it is crowded, the game will be more enjoyable. Children, who do not participate in the game, should get the minimum score. For this reason, they give them the smallest number value. When naming is considered in this way, it gets easier for her and thanks her mother. Now, Sude impatiently waits for the school day.

The views of the science pre-service teachers on the use of stories in science courses have been evaluated and categorized under themes. As is shown in Figure 1, the views of the pre-service teachers on the use of stories in science courses have been categorized under 6 themes including entertaining and enjoyable, increasing imagination and creative thinking, better understanding and catchy, interesting, abstract-to-concrete, associating with the daily life.

\section{Entertaining and Enjoyable}

When the views of the science pre-service teachers on the use of stories in science courses are examined, some sample statements (T1, T6, T9, T10, T18, T19, T23, T24, T25 T26, T27, T29, T32, T34, T37, T40, T42, T44, T45, T51, T52, T59, T68), in which the pre-service teachers identify the use of stories in science courses as "entertaining and enjoyable", are presented below.

"...I think that the tale creation activities will make a great contribution to my teaching abilities. Because storifying any information to make it more entertaining rather than telling it in a straightforward way increases the interest of students on the course, and allows that information to be kept in the memory for a longer period of time..." (T10)

"...By designing such tales formystudents, I can make them learn in an enjoyable way and make them like the course..." (T18)

"... think that the tale creation activities will make the courses enjoyable, and it brings in lecturing ability in an instructive method, and it will be an activity that will make the students like the course indicating that course is not something made up of theoretical information..." (T19)

"...While I created this tale, I thought about how I can explain this subject in an easier way and make it more enjoyable so that my students can like the course..." (T23)

"... am sure that particularly starting the courses with such stories makes the course more entertaining by attracting students' attention far better..."(T24)

"...This is a teaching method, which I will be able to use in my future teacher career to make my students learn by enjoying..." (T26) 
VIEWS AND EXPERIENCES IF PRE-SERVICE TEACHERS IN THE USE GF STIRIES IN

TEACHING SCIENCE

ISSN 1648-3898 /Print/

(P. 605-619)

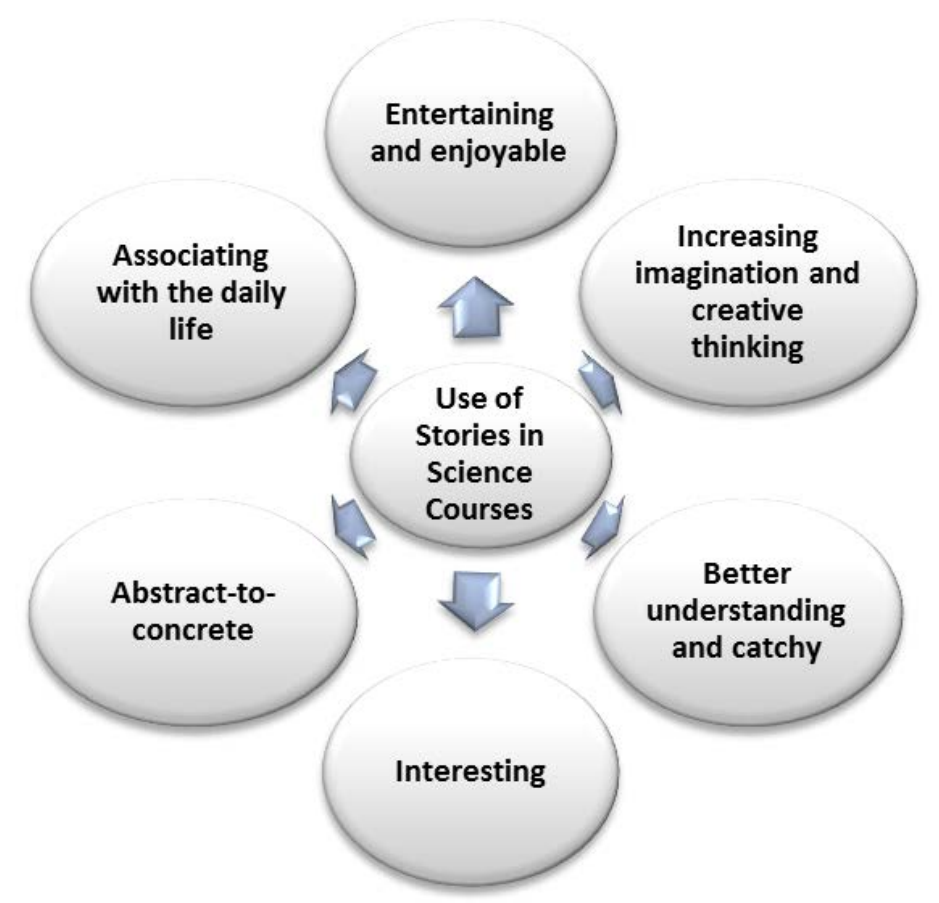

Figure1. Themes of views of science pre-service teachers on the use of stories in science courses.

\footnotetext{
"... believe that I will use the tale creation activities in my future teacher career. Because it is entertaining both while writing and reading..." (T27)

"...Giving a lecture in a way attracting attention of students and arouse curiosity among students will make the course interesting and entertaining..." (T52)
}

The pre-service teachers have stated that teachers will make science courses entertaining by giving a lecture using stories in their careers. In their statements, the pre-service teachers have expressed that an entertaining course with students will make learning easier, arouse curiosity, increase the memorability of knowledge, and increase the interest and attitude of the students on the course by making it easier. It is seen in the statements of the science pre-service teachers that lecturing in an entertaining way by using stories in science courses make contributions on lecturing abilities and teaching abilities, and that they will use the stories in science courses in the future when they become teachers.

\section{Increasing Imagination and Creative Thinking}

Another theme formed based on the statements of the science pre-service teachers on the use of stories in science courses is the theme "Increasing imagination and creative thinking". In their statements, the science pre-service teachers ( $\mathrm{T} 1$, $\mathrm{T} 4$, $\mathrm{T} 6, \mathrm{~T} 8, \mathrm{~T} 9, \mathrm{~T} 11, \mathrm{~T} 12, \mathrm{~T} 13, \mathrm{~T} 16, \mathrm{~T} 17, \mathrm{~T} 22, \mathrm{~T} 32, \mathrm{~T} 43, \mathrm{~T} 44, \mathrm{~T} 47, \mathrm{~T} 49, \mathrm{~T} 58, \mathrm{~T} 60, \mathrm{~T} 65, \mathrm{~T} 71$ ) have expressed that the use of stories in courses increases imagination and brings in creative thinking ability.

"... think that writing stories helps me activate my imagination in order to put forward a creative idea..." (T4)

"...You needed to have information, have imagination and think in order to write a story. I have thought about how I can create different points of view, I think that my imagination has developed thanks to this..." (T8)

"...I have seen how much I can use my imagination ..." (T9)

"...Although many other stories come to my mind when I write a story, selecting the most convenient one develops imagination ability..." (T11)

"...Giving a lecture, which I have command, by using imagination and storifying it has made me think that if I explain a subject that my students cannot understand in the future by using this method, it will be more permanent and effective..." (T44) 
The pre-service teachers have stated that while creating stories, they transfer their knowledge to their students with a different point of view by using their creativity and imagination and emphasized the importance of imagination while creating stories.

"... did not like writing stories much and did not think in a creative way, but now I think in a wider perspective, it has contributed to my creative thinking ability..."(T6)

"...My multilateral thinking ability has developed, and I have overcome the prejudice that I cannot ever write stories and I have a very poor imagination..." (T16)

"...The story I have written has made me think in some more creative way. Because writing this story means creating something in your mind, and writing it down based on this creation process. Although l am not very good at these subjects, it helped me force my mind and brain. It was a good experience for me to write this story..." (T32)

Prior to the story creation process, the pre-service teachers were seen to be prejudiced about, did not like and felt themselves insufficient in writing stories, however, following the story creation process, they have stated that it contributes to creative and multifaceted thinking, they have realized their imagination, and in this context, writing stories has become a good experience for them.

"...In the future, I may make my students write stories. This will develop their imagination..." (T12)

"... As I have developed my own imagination, I think that I will also develop my students' imaginations by transferring this to them..." (T43)

"...I have thought that the subject will be understood much better by entering the imaginary world of children and telling about the hydrocarbons, which actually seem to be very complex, in a story..."(T47)

"...Describing the incomprehensible subjects with representations makes them more comprehensible. For this reason, storifying the subjects that we cannot understand will certainly make it easier to comprehend the subject. This is a more useful method for the primary school students. Since their imagination is more advanced, it is easy for them to imagine it and thus, it is understood better..." (T60)

The science pre-service teachers participating in the research have stated that in their career, they will apply teaching with stories in science courses, make their students write stories, this will contribute to development of their imaginations, the complex subjects will be simplified by way using imaginations through stories, and the courses will become more understandable.

\section{Better Understanding and Catchy}

The science pre-service teachers participating in the research have stated that teaching science with stories has a positive effect on better understanding the subjects and concepts, and also on their memorability $(T 1, T 2, T 3, T 6, T 7$, T9, T10,T11, T13, T14, T15, T16,T17, T18, T19, T22, T23, T24, T28, T,29, T32, T33, T35, T37, T38, T39, T40, T44, T45, T46, T47, T50, T51, T55, T56, T57, T59, T60, T61, T62, T63, T65, T68, T69, T71).

"... It is important to create a tale. Ultimately, the age range we will teach is very convenient for this, I may have difficulties in explaining children some tough subjects or the children may not understand them at all. At that very point, it can be very useful for me to explain the subject with stories..." (T3)

"...I think that the tale creation activities will make a great contribution to my teaching abilities. Because storifying any information to make it more entertaining rather than telling it in a straightforward way increases the interest of students on the course, and allows that information to be kept in the memory for a longer period of time..." (T10)

"...I think that it would be more memorable to tell the students something in different ways by storifying them rather than only by way of presentation. For this reason, it is more logical to explain the students hardly memorable topics in a way to attract interest of them..." (T16)

"...While creating my story I formed an opinion that this method can be used as well so that the subjects become more memorable for the students. By designing such tales for my students, I can make them learn in an enjoyable way and make them like the course..." (T18)

"...I have seen that if the hard and complicated subjects are explained or lectured by storifying them, both apparent and more memorable knowledge shall be achieved..." (T33) 


\footnotetext{
"...I think that when an incomprehensible subject or a new subject is explained to students by creating a story, it shall be more memorable..."(T56)
}

The pre-service teachers have stated that in the courses to be lectured using the stories, the stories make the courses more interesting and entertaining as compared to the straight narrative style, and that, thanks to this, knowledge of the students will be more memorable.

"...The most important task of the stories is to maintain, transfer and disperse thoughts, and to this end, the tale I have written has enabled me to command on the subject..." (T28)

T28 has expressed that it is necessary to think much while writing, thus, it enables to maintain thoughts and it is possible to apply through writing in teaching science.

"...It has become good experience to rescue the course from boringness in the future by telling a catchy story while lecturing..."(T19)

"... I think that when I become a teacher, I will ensure my students to learn in an easier and entertaining way by storifying the hard subjects with story creation activity and to make the subjects catchier through stories..." (T37)

"... I have visual intelligence, imagining and storifying things provides me with memorability. I can say that it is what I have needed so far. I have realized my imagination and creativity, which shall be useful both for me and for my students..." (T65)

The science pre-service teachers have the opinion that when they become teachers in the future, they shall give lectures to their students in a catchier way and without getting bored.

"... I think that the subject will be catcher when the teacher explains the abstract things by concretizing or in a way as the student can imagine. I think that it will help me make the complicated subjects more concrete and make the knowledge I teach more permanent. Perhaps the story creation activity will save me from being exposed to the phrase "Our teacher knows the subject well, but she cannot explain anything..." (T39)

In his/her statement, T39 has emphasized that just having knowledge is not sufficient, the important thing is that this knowledge is explained in a way and through as the students can understand it.

\section{Interesting}

Some of the pre-service teachers participating in the research $(\mathrm{T} 1, \mathrm{~T} 2, \mathrm{~T} 10, \mathrm{~T} 13, \mathrm{~T} 14, \mathrm{~T} 16, \mathrm{~T} 19, \mathrm{~T} 23, \mathrm{~T} 25, \mathrm{~T} 30, \mathrm{~T} 31$, $\mathrm{T} 34, \mathrm{~T} 35, \mathrm{~T} 36, \mathrm{~T} 44, \mathrm{~T} 47, \mathrm{~T} 48, \mathrm{~T} 52, \mathrm{~T} 57, \mathrm{~T} 68, \mathrm{~T} 70$ ) have the opinion that using such activities in courses in teaching science with stories increases interest to the course.

"...As using the direct instruction technique with our students makes the subject boring, it decreases interest to the course. For this reason, I think that preparing the subjects in stories will be a plus for us when we become teachers in the future, as we have already learned about it..." (T2)

"...I think that the tale creation activities will make a great contribution to my teaching abilities. Because storifying any information to make it more entertaining rather than telling it in a straightforward way increases the interest of students on the course, and allows that information to be kept in the memory for a longer period of time..." (T10)

"...The story creation activity ensures me to develop my abilities such as conceptual organization, effective communication, sufficient content knowledge, expression uniformity, and most importantly, my attraction getting abilities. Consequently, the activity becomes both entertaining and educational by ensuring the students to focus on the course..." (T34)

The statements of the pre-service teachers indicate that story writing in science will make great contributions to them in their careers. They have stated that their teaching abilities have increased, and conceptual organization, effective communication, expression uniformity, and most importantly, attraction getting abilities have developed. They have also stated that interest of students to the course shall increase thanks to stories. 
"...I think that it would be more memorable to tell the students something in different ways by storifying them rather than only by way of presentation. For this reason, it is more logical to explain the students hardly memorable topics in a way to attract interest of them..." (T16)

"... Interesting methods should be found in order to transfer the acquisitions at the knowledge level to the children. I think that storifying is one of these methods..." (T30)

"...It will be easier to adapt the students to the course by decreasing to their level, and consequently, its interesting side of narration will not bother the children..." (T44)

"...Giving a lecture in a way attracting attention of students and arouse curiosity among students will make the course interesting and entertaining..." (T52)

"...If I explain the courses with stories when necessary, the course will be very entertaining. When my students listen to the courses in a willing and interesting way, they will never forget that subject..." (T68)

T1 has stated that teaching science with stories shall contribute not only to science courses but also to the interdisciplinary students, the interest of students to literature will increase by way of writing stories.

"...I think that it will help increase interest of children to literature, although it is not related to our field. I think that this method is a quite effective method..." (T1)

\section{Abstract-to-Concrete}

Some of the science pre-service teachers $(\mathrm{T} 4, \mathrm{~T} 8, \mathrm{~T} 16, \mathrm{~T} 22, \mathrm{~T} 29, \mathrm{~T} 32, \mathrm{~T} 39, \mathrm{~T} 66)$ have stated that the abstract concepts that we encounter in the science subjects can be lectured with stories by way of concretizing.

"...We know that learning level or course perception level, level of concretizing abstract concepts and their problems experienced vary. For this reason, I can start story creation activities with my students having such problems and try to provide equivalent learning..." (T4)

"...When we become teachers, we will have to tell and transfer something to the students. However, the things that we will tell will not be concrete all the time, but we will also tell about abstract things. Thanks to narration, we can help the children understand more easily by imitating the abstract things to concrete ones..." (T8)

"...If we consider that we will give lectures to the primary school students, we can decrease to the level of these students thanks to narration. Or I think that it willenable us to tell about the abstractevents in an easier and permanent way by concretizing..." (T22)

"...If the teacher tells about an abstract subject by way of concretizing, it will be more memorable for the students. He/she can do that in an entertaining way by way of narration. The students can both entertain and learn the complicated subjects. In this way, it will be more memorable..." (T29)

"...I think that trying to instruct a subject to my students with more concrete things will be more effective and memorable for them, and at the same time, this narration activity will make the course more entertaining and fascinating..." (T32)

"...I think that the subject will be catcher when the teacher explains the abstract things by concretizing or in a way as the student can imagine. I think that it will help me make the complicated subjects more concrete and make the knowledge I teach more permanent. Perhaps the story creation activity will save me from being exposed to the phrase "Our teacher knows the subject well, but she cannot explain anything..." (T39)

In the statements of the pre-service teachers specified under this headline, it is expressed that it shall be an effective method to concretize the abstract concepts in teaching science by using stories. It has been emphasized that in this way, the students shall have a more effective and memorable learning in a more entertaining and fascinating course environment.

\section{Associating with the Daily Life}

The statements of the pre-service teachers (T14,T17,T22,T46, T55) on "associating with the daily life", the last theme formed based on the statements of the pre-service teachers on the use of stories in teaching science, are presented below.

"...I think that I enable the students to understand better and I develop them by attracting their attention by combining the daily life with the course through story creation activity..." (T14) 
"...As pre-service teachers, we can make the courses more understandable both through the real life and such stories. The knowledge and ability level of the students can be developed more..." (T17)

"...Writing the story, I got influenced by many things happening around me. I think that I have written a different story thanks to my sibling's book, vegetables in the kitchen, advertisements on TV and similar events..." (T22)

"...When the children do not understand the subject, we can instruct them by performing such different applications. The more you associate a subject with the normal life, the more it will contribute to the students..." (T46)

"...If we perform more association and adaptation with the daily life by way of writing stories, and provide the students with the real- life stories related to the subject, I believe that we will receive very useful results..." (T47)

The pre-service teachers have emphasized that the subjects are associated with the daily through teaching with stories, and they constitute a bridge between theoretical knowledge and practical knowledge, and consequently, these concepts and subjects become more understandable and interesting. They have pointed out that associating with the daily life shall make positive contributions to learning, and it shall develop students' knowledge and abilities.

\section{Discussion}

As a result of this research, the views of the science pre-service teachers on the use of stories in organic chemistry courses and their views on the use of story in the science courses a result of the stories created have been evaluated and categorized under themes. The views of the pre-service teachers on the use of stories in science courses have been categorized under 6 themes including "entertaining and enjoyable", "increasing imagination and creative thinking", "better understanding and catchy", "interesting", "abstract-to-concrete", "associating with the daily life".

Under the "entertaining and enjoyable"theme, the pre-service teachers have expressed that they shall use stories in their careers, and through this method, the science courses shall be more entertaining, the interest and attitude of the students on the course shall increase. The story telling method is one of the methods that have frequently been applied in many areas of education for very long years. Considering the fact that stories are loved by children (Rose, 2017), it is almost certain that lessons given through stories would create a fun learning environment.

One of the most important reasons of this is that the stories have an entertaining part. The students learn in an active way in an entertaining learning environment (Gölcük, 2017). In a similar research, although the students see it as an entertainment opportunity without realizing that they learn new concepts while having joy, they have understood that they have internalized the scientific events thanks to the stories, and that the stories have a teaching effect. It has been seen that the scientific stories make a significant difference on learning process of the students (Akarsu, Kariper \& Coşkun, 2015).

Educational sciences have long used stories as an educational tool. Evidence demonstrates that not only an interesting and intriguing story itself but also using this technique supports learning and remembering (Rose, 2017). The science pre-service teachers participating in the research have stated that they shall improve the lecturing abilities giving lectures in an entertaining way by using stories in science courses, and that when they become teachers, they will apply teaching with stories in science courses. Although the use of stories in teaching science was theoretically justified by Bruner (1985, 1991 in the past, it is not used in a widespread fashion in teaching science. However, it is believed that the unique qualities of stories can positively contribute when teaching science. As a result of their research, Kariper and Coşkun (2015) have stated that teaching with stories has brought in the teachers a new perspective, and that it has affected the classroom environment in a positive way. The studies conducted also indicate that learning with joy affects the education-training process in a positive way.

In the statements of the pre-service teachers under the "increasing imagination and creative thinking" theme, the pre-service teachers have stated that while creating stories, they transfer their knowledge to their students with a different point of view by using their creativity and imagination and emphasized the importance of imagination while creating stories. Creativity is a way of thinking and it is closely related to imagination. In fact, each individual has his own unique creative qualities. However, these qualities should be improved using various ways. Creativity has always been a source of wonder and joy. It will also be an important factor in schools in the future therefore creative skills of young people should be improved (Gibson, 2005). Creativity has been defined as "Being sensitive against problems, malfunctions, lack of knowledge, lost elements, inadaptability, seeking solutions for difficulty and foretelling" (Özden, 2003; Torrance, 1966). The stories develop imagination of the students with its transfusion characteristic (Egan,1992; Yakıncı, Almış, \& Kavruk, 2012). Therefore, storytelling activities in schools can contribute both to the development of imagination and creativity of students. According to Sever (2003), the story text should address students in terms of 
age, interest and need, and students' imaginary and emotion world should be in harmony with the content pattern of texts. Since such learning environments shall be more sincere and familiar for the students, learning shall be realized in an easier way.

Teaching science is always based on reasoning, experimental and analytical thinking. Since students usually see science lessons as boring and difficult to understand, there is a risk that their interest in learning science and their creativity may gradually decrease. Stories can be used to teach science in order to prevent this. However, story and storytelling are not used extensively in science lessons (Rose, 2017). The science pre-service teachers participating in the research have stated that in their career, they will apply teaching with stories in science courses, make their students write stories, this will contribute to development of their imaginations, the complex subjects will be simplified by way using imaginations through stories, and the courses will become more understandable. It is an important requirement for the individuals to make attempts to reveal and develop their creativity power, so that our country can have a place among the developed countries. For this reason, the constructivist approach, in which the activities revealing creativity are in the forefront, has a place in our education system (Pekmezci, 2014). Because learning is something which a person can do on his own and according to his competencies.

Prior to the story creation process, the pre-service teachers were seen to be prejudiced about, did not like and felt themselves insufficient in writing stories, however, following the story creation process, they have stated that it contributes to creative and multifaceted thinking, they have realized their imagination, and in this context, writing stories has become a good experience for them. There are many scientific studies which intend to establish a theoretical background using science stories (Klassen 2006; Kubli 2001; Metz, Klassen, McMillan, Clough \& Olson, 2007; Norris, Guilbert, Smith, Hakimelahi \& Phillips, 2005). Klassen (2009) conducted a research about how a science story can be researched, written and analysed and how students can react to and interpret a story in order to provide a basis to write effective science stories. Norris et al. (2005) developed some criteria to evaluate science stories. This actually shows that the challenges and worries that pre-service teachers experience when writing stories are normal in the beginning. Senemoğlu (2007) has emphasized that first of all, teachers should be trained as equipped with these properties and they should have creativity properties, so that creativity can be developed. Bringing up creative generations is possible through the teachers, who can think fluently, flexibly and originally and who can organize such environments as required for this purpose. In this context, it is important for the pre-service teachers participating in the research to realize their imagination and creativity and declare positive opinions.

The human brain is believed to store the information presented in a story format longer than when given as a list of unrelated facts (Haven, 2000; Weaver, 1994). The stories are very important tools, which try to make information meaningful, and are made up of associated and consistent information (Millar \& Osbome, 1998). Under the "better understanding and catchy" theme, the pre-service teachers have stated that students shall understand the concepts and subjects better in the courses conducted using stories and things learned through this method shall be more memorable. In their papers, Demircioğlu et al. (2006) have stated that the chemical stories increase students' willingness towards learning and realize meaningful learning. In another research, it has been concluded that the stories develop problem-solving abilities and imagination of the individuals and support their creativity, affect their language and social development in a positive way, and also explaining a complex event with stories shall activate emotions of the individuals in their fantastic worlds and realize meaningful learning (Turgut and Kışla, 2015). As the students discover things through the story creation method, they better understand the concepts, and their learning environments are more sincere and familiar for the students. Ritchie, Rigano and Duane (2008) created a story titled "ecological mystery" together with fourth grade students and teachers in their research. They reached the conclusion that the support the students received from their teachers when creating the story helped them to understand and learn the science concept better which led to permanent learning. Going ahead from this point of view, it can be said that storifying is used as an effective and permanent teaching method. In the same way, many studies indicate that meaningful and permanent learning shall be ensured thanks to learning with stories (Banister \& Ryan, 2001; Fensham, 2001). Again, a research by Ramsden (1997) found that learning activities using explanatory tools when teaching topics such as chemical changes and conservation of mass in chemical reactions contributed significantly to learning.

Under the "interesting" for them, the pre-service teachers have stated that the story creation method has made positive contributions for them. They have stated that their teaching abilities have increased, and conceptual organization, effective communication, expression uniformity, and most importantly, attraction getting abilities have developed. They have also stated that interest of students to the course shall increase thanks to stories. An important advantage of the stories is that the students can become parts of a story as an actor or they help telling a story. In this respect, the stories can increase interest of the students, especially those with low motivation (Barry et al., 2005). Being the oldest 
tool of communication, story-telling can make the information, events and learning related to science more enjoyable and desirable by contributing to science.

It is important to simplify the meaningful ways of transferring knowledge to the children, who are especially in the concrete procedures period. It is one of the most important duties of teachers within this process to concretize a course in which abstract concepts are taught, to use the knowledge learned by the students with stories and associate them with the daily life, to develop enjoyable learning environments while learning and applying by getting away from the traditional teaching understanding (Şahin, 1998; Üstünoğlu, 1990). The students included in the 9-12 age group can comprehend ideas through symbols, and learn the basic abstract concepts, whose contents they cannot fully understand, only with the help of concrete concepts (Erden \& Akman, 2005). Stories can be used to explain abstract ideas and concepts. Abstract concepts are the most effective tools in making stories meaningful. (Wells, 1987)

In the statements of the pre-service teachers specified under the "abstract-to-concrete" theme, it has been emphasized that the problems shall be concretized by using stories in teaching abstract concepts and that in this way, the students shall have a more effective and memorable learning in a more entertaining and fascinating course environment. The results specified under the "abstract-to-concrete", in our research resemble with the results of another research carried out on the use of stories in medical education. According to the research, when the knowledge provided during medical education is not associated with the daily life events, it has been observed that the students, who have received this education, often memorize this knowledge only for the exam and it turns it into abstract concepts being forgotten after the exam (Yakıncı, Almış, \& Kavruk, 2012). It has been concluded that the knowledge can be concretized by applying to the simplifying and mnemonic methods, and during this process, the story texts have such characteristics that motivate and increase the learning desire. Science, especially chemistry, is seen as a difficult discipline to be hardly understood by students as it contains very abstract ideas. For this reason, it can be thought that the use of storifying in science teaching can be effective. Banister and Ryan (2001) reported that there was an increasing concern in expanding the ways of teaching science to children and conducted a research about the use of stories to improve children's ideas about water cycle and found that children remembered information longer when they learned through stories.

Under the theme of "associating with the daily life", the pre-service teachers have emphasized that the subjects are associated with the daily life through teaching with stories, and they constitute a bridge between theoretical knowledge and practical knowledge, and consequently, these concepts and subjects become more understandable and interesting. They have pointed out that associating with the daily life shall make positive contributions to learning, and it shall develop students' knowledge and abilities. Bostrom (as cited in Avraamidouve Osborne, 2009) reported that stories created by students and teachers made lessons in the schools more meaningful for students. It is easier for the people who have strong social skills to connect science to the real world. Studies demonstrate that stories support language development but also can have a positive effect on social development of children (Isbell, Lindauer, Lowrance \& Sobol, 2000; Morris, Taylor \&Wilson, 2000).

One of the most important aims of education and training is to ensure that the students inquire knowledge with a critical point of view, integrate it with their own lives, and bring the students up as scientific literates with high scientific thinking power. The use of stories in science education is among the methods in which the students can actively participate, which explains any science they see around them, and increases their interests towards science (Demircioğlu, Demircioğlu, \& Ayas, 2006). It is important to use the stories in the courses so that the students can interpret the events they encounter in their daily lives in order to contribute to the excitement of solving the problems (Demircioğlu, Demircioğlu, \& Ayas, 2006; Pekmezci, 2014; Türkmen \& Ünver, 2012).

\section{Conclusions}

When all the results obtained under these themes are evaluated in a holistic way, it is seen that the views of the science pre-service teachers on the use of the stories created as part of organic chemistry courses in science courses are positive. Teachers candidates also reported that they would use stories when teaching science. It has been concluded that teaching science with stories shall contribute to the knowledge and abilities of both teachers and students, and consequently, the science courses shall be more entertaining, enjoyable and interesting. In addition, it has been understood from the statements of teacher candidates that creativity of students shall develop in the story composition process, their imagination shall increase, they shall configure their knowledge associating them with the daily life, meaningful learning shall be ensured by concretizing mostly abstract science subjects and concepts through stories, and a learning environment to ensure memorability of knowledge shall be prepared.

Pre-service teachers had prejudice about and did not like writing stories and even thought themselves as incapable 
before they started to write stories. However, it was observed that they realised their creativity and imagination skills through divergent thinking in the story creation process; they could connect stories to real life experiences and enjoyed writing stories and that the whole story writing process was an effective and fun experience for them.

As a result of the study, it is seen that the use of the stories in science teaching will lead to an effective learning of science. The stories describe the real parts of human life or an event that people have associated with their lives. Thus, the creation of science stories by associating the universal tools of the stories with the universal nature of science is an effective method that can be used in science teaching in almost all countries. Since the stories are related basically to everyday life, the fact that science subjects can also be associated with the daily life is a method that teachers and students can prefer in science education. Since scientific teaching is fun and provides memorability through the stories, it is thought that the learning with stories is an effective tool to structure and use the science subjects by the students, and it is possible to use them in every country and culture because of their characteristics. For this reason, it is also important that the stories are included in the science education in order to create an environment, where the students can use their creativity and imagination in the science courses. Especially, it will be useful for both the teacher candidates and science education students that, in the future, the teacher candidates, who will take the science courses, will be able to improve themselves, when they start teaching.

\section{References}

Akarsu, B., Kariper, I. A., \& Coşkun, H. (2015). The effect of using scientific stories on teaching science and on the academic achievement of the students. Mersin Üniversitesi Eğitim Fakültesi Dergisi, 11 (2), 349-365.

Akçay, H., Özyurt, B. B., \& Akçay, B. B. (2014). Çoklu yazma etkinliklerinin fen ve teknoloji dersi öğretiminde kullanilmasinin öğrenci başarisi ve kavram öğrenmeye etkisi [The impacts of multimodal writing opportunities on science and technology teaching concerning student achievement and concept learning]. Bayburt Eğitim Fakültesi Dergisi, 9 (2), 15-31.

Akkuş, R., Günel M., \& Hand B. (2007). Comparing an ınquiry-based approach known as the science writing heuristic to traditional science teaching practices: are there differences? International Journal of Science Education 29 (14), 1745-1765.

Akyol, C., \& Dikici, A. (2009). Şiirle öğretim tekniğinin öğrencilerin başarı ve tutumlarına etkisi [The effect of poetical teaching technique on academic achievement and attitude of the students]. Illkögretim Online, 8 (1), 48-56.

Appleton, K. (2003). How do beginning primary school teachers cope with science? Toward an understanding of science teaching practice. Research in Science Education, 33 (1), 1-25.

Avraamidou, L., \& Osborne, J. (2009). The role of narrative in communication science. International Journal of Science Education, 31 (12), 1683-1707.

Ayas, A. P. (1995). Fen bilimlerinde program geliştirme ve uygulama teknikleri üzerine bir çalışma: íki çağdaş yaklaşımın değerlendirilmesi [A study on the techniques for program development and practice in science: Evaluation of two contemporary approaches]. Hacettepe Üniversitesi Eğitim Fakültesi Dergisi, 11, 149-155.

Ayvacı, H. Ş., \& Şenel Çoruhlu, T. (2009). Fiziksel ve kimyasal değişim konularindaki kavram yanilgilarinin düzeltilmesinde açiklayici hikâye yönteminin etkisi [Effects of explanatory stories on elimination of students' misconceptions about physical and chemical change]. Ondokuz Mayis University Journal of Education, 28 (1), 93-104.

Banister, F., \& Ryan, C. (2001). Developing science concepts through story-telling. School Science Review, 83 (302), 75-83.

Barry, A. M., Berry, D., Cunningham, S., Newton, I., Schweppe, M., Spalter, A., Whiteley, W. \&Williams, R. 2002. (Edited by: Judith R. Brown). Visual learning for science and engineering. Retrieved from http://education.siggraph.org/conferences/other/visual-learning.

Bostan Sarioğlan, A. (2014). Comparison of science teacher candidates' metacognitive and scientific story writing skills. International Journal on New Trends in Education \& their Implications (IJONTE), 5 (2), 126-133.

Bruner, J. (1985). Narrative and paradigmatic modes of thought. In Eisner E. (Ed.), Learning and teaching the ways of knowing (pp 97115). Chicago: National Society for the Studies of Education (NSSE).

Bruner J. (1991). The narrative construction of reality. Critical Inquiry, 18 (1), 1-21.

Creswell, J. W. (2007). Qualitative inquiry and research design: Choosing among five approaches (2nd Ed.). USA: Sage.

Çalışkan, H. (2008). Eğitimcilerin araştırmaya dayalı öğrenme yaklaşımıyla ilgili algıları [The perceptions of educators on inquiry-based learning approach]. Gazi Eğitim Fakültesi Dergisi, 28 (1), 153-170.

Çıralı, H., \&Usluel, Y. K. (2015). A descriptive review study about digital storytelling in educational context. In: Proceedings of Edulearn 15 Conference (pp. 5026-5034). Barcelona, Spain.

Demircioğlu, H., Demircioğlu, G., \& Ayas, A. (2006). Hikayeler ve kimya öğretimi [Storyllnes and chemistry teacing]. Hacettepe Üniversitesi Eğitim Fakültesi Dergisi, 30, 110-119.

Dilidüzgün S. (2003). Çağdaş çocuk yazını-yazın eğitimine atılan ilk adım [Contemporary children's literature - first step into literary writing education]. 2. Baskı, (pp. 96). İstanbul: Morpa Kültür Yayınları.

Duman, B., \& Göçen, G. (2015). The effect of the digital storytelling method on pre-service teachers' creative writing skills. Anthropologist, $20(1-2), 215-222$.

Duru, M. K., \& Gürdal, A. (2002). illköğretim fen ve teknoloji dersinde kavram haritasıyla ve gruplara kavram haritası çizdirilerek öğretimin öğrenci başarısına etkisi [The effect of using concept map and making groups draw concept maps in science and technology lessons on the success of students]. V. Ulusal Fen Bilimleri ve Matematik Eğitimi Kongresi, Bildiriler Kitabı, (1), (pp. 310-316). ODTÜ, Ankara. 
Erden, M., \& Akman, Y. (2005). Gelişim ve öğrenme [Development and learning]. Ankara: Arkadaş Yayınları.

Ersoy, A. F. (2016). Fenomenoloji. Eğitimde nitel araştırma desenleri [Phenomenology. Qualitative research designs in education]. (Ed: A. Saban \& A. Ersoy), (ss. 51-56). Ankara: Anı Yayıncilık.

Erten, S., Kiray, S. A., \& Sen-Gumus, B. (2013). Influence of scientific stories on students' ideas about science and scientists. International Journal of Education in Mathematics, Science and Technology, 1 (2), 122-137.

Fensham, P. (2001, June). Science as story: Science education by story. In Asia-Pacific Forum on Science Learning and Teaching, 2 (1), 1-5. The Education University of Hong Kong, Department of Science and Environmental Studies.

Gibson, H. (2005). What creativity isn't: The presumptions of instrumental and individual justifications for creativity in education. British Journal of Educational Studies, 53 (2), 148-167.

Ghaffari, S. (2006). A laboratory experiment using molecular models for an introductory chemistry class. Journal of Chemical Education, $83(8), 1182$.

Gölcük, A. (2017). Bilimsel hikayelerle desteklenen fen eğitiminin öğrencilerin yaratıclıkları ve duyuşsal özellikleri üzerindeki etkileri [The effect of science education that is supported by scientific stories on students' creativity and affective properties]. (Master's thesis). http://hdl.handle.net/11655/3912. Hacettepe University Eğitim Bilimleri Enstitüsü, Ankara.

Günel, M., Atila, M. E., \& Büyükkasap, E. (2009). Farklı betimleme modlarının öğrenme amaçlı yazma aktivitelerinde kullanımlarının 6. sınıf yaşamımızdaki elektrik ünitesinin öğrenimine etkisi [The impact of using multi modal representations within writing to learn activities on learning electricity unit at 6th grade]. Ilköğretim online, 8 (1), 183-198.

Hand, B., Hohenshell, L., \& Prain V. (2004). Exploring students'responses to conceptual questions when engaged with planned writing experiences: A study with year 10 science Students. Journal of Research in Science Teaching, 41 (2) 186-210.

Hand, B., Prain, V., \& Wallace, C. (2002). Influences of writing tasks on students' answers to recall and higher- level test questions. Research in Science Education, 32 (1), 19-34.

Haven, K. F. (2000). Super simple storytelling: A can-do guide for every classroom, every day. Libraries Unlimited

Heering, P. (2014). Scientific practices as cultural activities: A challenge and an opportunity for education. Journal of Baltic Science Education, 13 (3), 296-297.

Hohenshell, L. M., \& Hand, B. (2006). Writing-to-learn strategies in secondary school cell biology: A mixed method study. International Journal of Science Education, 28 (2), 261-289.

Isbell, R., Sobol, J., Lindauer, L., \& Lowrance, A. (2004). The effects of storytelling and story reading on the oral language complexity and story comprehension of young children. Early Childhood Education Journal, 32 (3), 157-163.

Kirby, D. A. (2018). Harnessing the persuasive power of narrative: science, storytelling, and movie censorship, 1930-1968. Science in Context, 31 (1), 85-106.

Klassen, S. (2006). A theoretical framework for contextual science teaching. Interchange, 37 (1-2), 31-62.

Klassen, S. (2009). The construction and analysis of a science story: A proposed methodology. Science \& Education, 18 (3-4), $401-423$.

Köklükaya, A. N. (2015). The determination of opinions of pre-service science teachers on the curriculum of science courses on the basis of the 3-idiots movie. Journal of Baltic Science Education, 14 (3), 366-378.

Kubli, F. (2001). Can the theory of narratives help science teachers be better storytellers? Science \& Education, 10 (6), 595-599.

Kumari, P. ( 2014). Story telling: A tool in teaching science. International Research Journal of Human Resources and Social Sciences, 1 (3), 53-61.

Lowenthal, P. R., \& Dunlap, J. C. (2010). From pixel on a screen to real person in your students'lives: Establishing social presence using digital storytelling. The Internet and Higher Education, 13 (1-2), 70-72.

Maskan, A, K., \& Maskan, M. H. (2007). İlköğretim 4. sınıf fen ve teknoloji ders kitabının değerlendirme ölçütleri yönünden incelenmesi [The investigation of the $4^{\text {th }}$ grade primary school science and technology textbook by the evaluative criteria]. D.Ü.Ziya Gökalp Eğitim Fakültesi Dergisi, 9, 22-32

Mason, L., \& Boscolo, P. (2000). Writing and conceptual change. What changes? Instructional Science, 28 (3), 199-226.

Merriam, S. B. (2013). Nitel araştırma: Desen ve uygulama için bir rehber [Qualitative research: A guide for design and application]. S. Turan (Trans. Ed.). Ankara: Nobel Yayıncilık.

Metz, D., Klassen,S., McMillan, B., Clough, M., \& Olson, J. (2007). Building a foundation for the use of historical narratives. Science \& Education, 16 (3-5), 313-334.

Miles, M. B., \& Huberman, A. M. (1994). Qualitative data analysis: An expanded sourcebook. London: Sage.

Millar, R., \& Osborne, J. (1998). Beyond 2000: Science education for the future (the report of a seminar series funded by the Nuffield Foundation). London: King's College London, School of Education.

Milne, C. (1998). Philosophically correct science stories? Examining the implications of heroic science stories for school science. Journal of Research in Science Teaching, 35 (2), 175-187.

Morris, V. G., Taylor, S. I., \& Wilson, J. T. (2000). Using children's stories to promote peace in classrooms. Early Childhood Education Journal, $28(1), 41-50$.

Mutonyi, H. (2016). Stories, proverbs, and anecdotes as scaffolds for learning science concepts. Journal of Research in Science Teaching, $53(6), 943-971$.

Norris, S. P.,Guilbert, S.M., Smith, M.L., Hakimelahi, S., \& Phillips, L.M. (2005). A theoretical framework for narrative explanation in science. Science Education, 89 (4), 535-563.

Oğuzkan, Ş. (1987). Orta dereceli kız teknik öğretim okulları okul öncesi eğitimi [Vocational technical education for girls, preschool education]. Ankara: Milli Eğitim Bakanlığı.

Orcan, A., \& Ingec, S. K. (2016). The effect of science-fiction stories developed by comics technique on creative thinking skills in physics teaching. Hacettepe Universitesi Egitim Fakultesi Dergisi-Hacettepe University Journal of Education, 31 (4), 628-643. 
Osborne, J. W. (1997). Identification with academics and academic success among community college students. Community College Review, $25(1), 59-67$.

Özden, Y. (2003). Öğrenme ve öğretme [Learning and teaching]. Ankara: Pegem A Yayıncılık.

Patton, M. Q. (2014). Nitel araştırma ve değerlendirmeyöntemleri [Qualitative research and evaluation methods]. M. Bütün \& S. B. Demir (Trans. Ed.) Ankara: Pegem Akademi.

Pekmezci, S. (2014). Bilişim teknolojileri destekli kısa hikayelerin öğrencilerin başarıları özyeterlik algıları ve fene yönelik tutumlarına etkisi [Effects of short stories reinforced with information technology on students' success, their self-efficacy and their attitudes towards science], (Master's thesis). http://hdl.handle.net/11499/2175. Pamukkale Üniversitesi Eğitim Bilimleri Enstitüsü, Denizli.

Ødegaard, M. (2003). Dramatic science: A critical review of drama. Studies in Science Education 39, 75-102.

Ramsden, J. M. (1997). How does a context-based approach influence understanding of key chemical ideas at 16+? International Journal of Science Education, 19 (6), 697-710.

Ritchie, S., Rigano, D., \& Duane, A. (2008). Writing an ecological mystery in class: Merging genres and learning science. International Journal of Science Education, 30, 143-166.

Rose, J. A. (2017). To teach science, tell stories. http://hdl.handle.net/10161/14346.

Saban, A. (2001). Çoklu zeka teorisi ve eğitim [Multiple intelligence theory and education]. Ankara: Nobel Yayın Dağıtım.

Senemoglu, N. (2007). Gelişim öğrenme ve öğretim [Development, learning and teaching]. Ankara: Gönül Yayıncılık.

Sever, S. (2003). Türkçe öğretiminde yeni yapılanma çalışmaları [New structuring studies in Turkish teaching]. Türklük Bilimi Araștırmaları, $13,27-38$

Schunk, D. H. (1990). Goal setting and self-efficacy during self-regulated learning. Educational Psychologist, 25 (1), 71-86.

Smith, J. A., Flowers, P., \& Larkin, M. (2009). Interpretative phenomenological analysis: Theory, method and research. Thousand Oaks, CA: Sage

Strauss, K. (2006). Teaching science with stories. Retrieved from http://www.naturestory.com/teachingsciencew.html.

Şahin, F. (1998). Okul öncesinde fen bilgisi öğretimi [Science teaching in preschool]. İstanbul: Beta Bas. Yay. Dağı. A.Ş.

Tao, P. K. (2002). A study of students' focal awareness when studying science stories designed for fostering understanding of the nature of science. Research in Science Education, 32 (1), 97-120.

Tıngöy, Ö., Güneşer, A., Öngün, E., Demirağ, A., \& Köroğlu, O. (2006). Using storytelling in education. 4th International Symposium of Interactive Media Design, 30 April 2006, İstanbul.

Torrance, E. P. (1966). Torrance tests of creative thinking:Directions manual and scoring guide. Bensenville, IL: Scholastic Testing Service.

Turgut, G., \& Kışla, T. (2015). Bilgisayar destekli hikâye anlatımı yöntemi: Alanyazın araştırması [The use of computer-aided story in education: Literature review]. Turkish Online Journal of Qualitative Inquiry, 6 (2), 97-121.

Turkmen, H., \& Ünver, E. (2012). Fen eğitiminde hikayelendirme tekniği [The narrative technique in science education]. Journal of European Education, 2 (1), 9-13.

Uluğ, F. (2004). Okulda başarı: Etkili öğrenme ve ders çalışma yöntemleri [Success in school: Effective learning and study methods]. İstanbul: Remzi Kitabevi.

Unal, G., \& Akpinar, E. (2006). To what extent science teachers are constructivist in their classrooms? Journal of Baltic Science Education, $2(10), 40-50$

Üstünoğlu, Ü. (1990). Okulöncesi öğretmenlerinin uzaktan öğretim yöntemiyle yetiştirilmesine yönelik program modeli [Model programs for training of preschool teachers through distance education methods]. Eskişehir Anadolu Üni. Eğitim Fakültesi Dergisi, 3 (1), 136-138.

Weaver, M. (Ed.). (1994). Tales as tools: The power of story in the classroom. Jonesborough, TN: National Storytelling Association Press. Wells, G. (1987). The meaning makers: children learning language and using language to learn. London: Hodder and Stoughton

Yakıncı, C., Almış, H., \& Kavruk, H. (2012). Tıp eğitiminde hikâyenin gücü [The power of story-telling in medical education]. Çocuk Sağlığı ve Hastalıkları Dergisi, 55 (4), 211-215.

Yildirim, A., \& Şimşek, H. (2005). Sosyal bilimlerde nitel araştırma yöntemleri [Qualitative research methods in the social sciences]. Ankara: Seçkin Yayıncılık.

Zembat, R., \& Zülfıkar, S. (2006). An investigation of conversation and storytelling activities used by preschool education teachers. Educational Sciences: Theory \& Practice, 6, 602-608. 